\title{
Identification COVID-19 Cases in Indonesia with The Double Exponential Smoothing Method
}

\author{
Sri Harini \\ UIN Maulana Malik Ibrahim Malang, sriharini@mat.uin-malang.ac.id
}

doi: https://doi.org/10.15642/mantik.2020.6.1.66-75

\begin{abstract}
Abstrak: Pendekatan time-series adalah metode yang digunakan untuk menganalisis serangkaian data dalam urutan waktu untuk memperkirakan nilai suatu seri di masa depan. Dalam artikel ini akan di identifkasi kasus COVID-19 di Indonesia menggunakan Metode Double Eksponensial Smoothing. Metode Double Eksponensial Smoothing merupakan salah satu metode yang dapat digunakan untuk pengoptimalkan pendugaan dari model ARIMA dengan parameter pemulusan $\alpha$. Data yang digunakan bersumber dari Badan Nasional Penanggulangan Bencana yang dirilis mulai 2 Maret 2020. Berdasarkan hasil pengujian PACF, ACF dan estimasi parameter model ARIMA pada kasus Covid-19 di Indonesia mengikuti model ARIMA $(0,1,1)$.
\end{abstract}

Kata Kunci: Time series; COVID-19; Double Eksponensial Smoothing; ARIMA

Abstract: The time-series approach is a method used to analyze a series of data in a time sequence to estimate the value of a series in the future. This article will identification the COVID-19 case model in Indonesia using the Double Exponential Smoothing Method. The Double Exponential Smoothing method is one method that can be used to optimize the estimation of the ARIMA model with smoothing parameters $\alpha$. The data used is sourced from the National Disaster Management Agency which was released starting March 2, 2020. Based on the results of PACF, ACF, and estimated parameters of the ARIMA model in the Covid-19 case in Indonesia following the ARIMA model $(0,1,1)$.

Keywords: Time series; COVID-19; Double Eksponensial Smoothing; ARIMA 


\section{Introduction}

In early 2020, the world was rocked by the emergence of a coronavirus (COVID-19) in Wuhan City, Hubei Province, China. COVID-19 is a new type of virus whose transmission from bats to humans causes upper respiratory infections such as Middle East Respiratory Syndrome (MERS-CoV) and Severe Acute Respiratory Syndrome (SARSCoV). Clinical manifestations of COVID-19 usually appear within 2 days to 14 days after exposure to common signs and symptoms of infection including acute respiratory disorders such as fever, coughing, and shortness of breath. Severe cases can cause pneumonia, acute respiratory syndrome, kidney failure, and even death [1]

On December 31, 2019, the WHO China Country Office reported a case of pneumonia of unknown etiology in Wuhan City, Hubei Province, China. On 7 January 2020, China identified pneumonia of unknown etiology as a new type of coronavirus (COVID-19). The increase in the number of COVID-19 cases has taken place quite quickly and has already spread to almost 208 countries in the world. As of April 7, 2020, based on data from Worldometers, up to 3:30 pm West Indonesia Time, April 7, 2020, the total number of positive cases of COVID-19 in the world had reached 1,379,175 patients. As many as 78,223 coronae positive patients worldwide have died and 294,149 people have successfully recovered from COVID-19 disease [2]. In addition, if referring to data from CSSE Johns Hopkins University, until 3:30 pm West Indonesia Time, April 6, 2020, the total number of positive cases of COVID-19 in the world was recorded at 1,277,962 patients with 69,527 COVID-19 patients had died and 264,048 people were successfully recovered. The highest number of positive COVID-19 cases in the world is in the United States, Spain, Italy, Germany, and France. While most deaths occurred in Italy, Spain, and France [3]

Likewise in Indonesia, as one of the countries affected by COVID-19 based on data from the Task Force for the Acceleration of Handling COVID-19 (BNPB) on April 7, 2020, which was renewed at $15.40 \mathrm{WIB}$, the total number of corona positive cases reached 2,731 patients with the number of COVID-positive patients 19 of those who are still undergoing treatment in Indonesia are 2,090 people or 83.9 percent of the total cases. An increase also occurred in the COVID-19 patient mortality rate until April 7, 2020, 221 positive COVID19 patients have died. The COVID-19 case fatality rate (CFR) in Indonesia currently reaches 8.39 percent. While COVID-19 positive patients who recovered increased to 204 people, equivalent to 7.7 percent of the total number of positive cases [4].

Seeing the development of COVID-19 case data updates that continue to increase and refer to previous research [5] to make patterns of bird flu spread from birds to humans in the form of mathematical models using the Differential Equation System. From the facts about bird flu, assumptions were formed which would later be used to make mathematical models. After the mathematical model is formed, then the stability of the model is searched, and the stability of the model is analyzed after that the model is simulated. [6] make a SIR model for the spread of bird flu. The SIR model is a mathematical model that explains the interaction between susceptible and infected bird population groups and susceptible, infected, and recovered human population groups. The equilibrium points of the model include disease-free equilibrium points and endemic equilibrium points. From the stability analysis, it is obtained that the stability of the balance point depends on the base reproduction number and the balance point is stable if the balance point is given population around the balance point.

Similar to pandemic influenza, rather than the other two coronaviruses [7]. In 1918, a significant proportion of the deaths were from pneumonia followed by influenza infection. The study proposed a model incorporating individual reaction, holiday effects as well as weather conditions (temperature in London, United Kingdom), which successfully captured the multiple-wave feature in the influenza-associated mortality in London In this study, we followed the form of individual reaction and governmental action effects. 
Establish the dynamics model of infectious diseases and time series models to predict the trend and short-term prediction of the transmission of COVID-19, which will be conducive to the intervention and prevention of COVID-19 by departments at all levels in mainland China and buy more time for clinical trials. [8] Based on the transmission mechanism of COVID-19 in the population and the implemented prevention and control measures, we establish the dynamic models of the six chambers, and establish the time series models based on different mathematical formulas according to the variation law of the original data. [9] proposes conceptual models for the COVID-19 outbreak in Wuhan with the consideration of individual behavioral reaction and governmental actions, e.g., holiday extension, travel restriction, hospitalization, and quarantine. We employe the estimates of these two key components from the 1918 influenza pandemic in London, United Kingdom, incorporated zoonotic introductions and the emigration, and then compute future trends and the reporting ratio. The model is concise in structure, and it successfully captures the course of the COVID-19 outbreak, and thus sheds light on understanding the trends of the outbreak.

Based on this background, this COVID-19 case in Indonesia will be predicted at this time using the Time-Series approach. Time-Series method is a quantitative method used to analyze a series of data collected in a time sequence and the results can be used as a reference to estimate the value of a series in the future [10].

\section{Methods}

Data in this research is taken from the tabulation of the Indonesian National Disaster Management Agency (BNPB) from 2 March until 7 April 2020 [4]. The Exponential Smoothing method and General Autoregressive Integrated Moving Average (ARIMA) processes refer to [10] with the following equation:

- Determine the first smoothing value and determine the parameter $\alpha$

$$
S_{t}^{\prime}=\alpha X+(1-\alpha) S_{t-1}^{\prime}
$$

- Determine the second smoothing value

$$
S_{t}^{\prime \prime}=\alpha S_{t}^{\prime}+(1-\alpha) S_{t-1}^{\prime \prime}
$$

- $\quad$ ARIMA Model For Time Series Data

ARIMA model is stated as follows:

$\phi(B)(1-B)^{d} X_{t}=\theta(B) Z_{t}$

This is an ARIMA process of order (p,d,q).

In general equation (3) can be approached using a regression model:

$y_{t}=\beta_{0}+\beta_{1} y_{t-1}+\cdots+\beta_{p} y_{t-p}+\beta_{1} e_{t-1}+\cdots+\beta_{q} e_{t-q}+\varepsilon_{t}$

\section{Results and Discussions}

The COVID-19 pandemic case in Indonesia has entered 1 month since 2 positive people were found on 2 March 2020. This condition continues to increase, with the latest data on 7 April 2020 recorded 2,738 people positive cases, 204 people recovery, and 221 people died. The COVID-19 pandemic certainly has a multi-sectoral impact, whether in the fields of education, health, defense, worship, social activities, or community economic activities.

To prevent the increasing number of COVID-19 cases in Indonesia, the government uses 4 regulations at once. Among them, Law 6/2018 on Health Quarantine, PP 21/2020 on Large-Scale Social Distancing (PSBB), Presidential Decree 11/2020 on Determination of Public Health Emergency, and Perppu 1/2020 on State Financial Policy and Financial System Stability. 
In addition, since the beginning, the government has also issued policies on social distancing, physical distancing, work from home (WFH) and large-social distancing (PSBB) for all levels of society. The aim of this policy is to break the distribution chain of COVID-19 in Indonesia. However, this condition is still not in line with government expectations, where more and more people are infected with COVID-19.

Table 1. COVID-19 Data From 2 March to 7 April 2020 (Source [4])

\begin{tabular}{rrrrrrrr}
\hline Date & Positive & Recovery & Death & Date & Positive & Recovery & \multicolumn{1}{l}{ Death } \\
\hline 2 & 2 & 0 & 0 & 21 & 450 & 20 & 38 \\
\hline 3 & 2 & 0 & 0 & 22 & 514 & 29 & 48 \\
\hline 4 & 2 & 0 & 0 & 23 & 579 & 30 & 49 \\
\hline 5 & 2 & 0 & 0 & 24 & 686 & 30 & 55 \\
\hline 6 & 2 & 0 & 0 & 25 & 790 & 31 & 58 \\
\hline 7 & 4 & 0 & 0 & 26 & 893 & 35 & 78 \\
\hline 8 & 6 & 0 & 0 & 27 & 1046 & 46 & 87 \\
\hline 9 & 19 & 0 & 0 & 28 & 1155 & 59 & 102 \\
\hline 10 & 27 & 0 & 0 & 29 & 1285 & 64 & 114 \\
\hline 11 & 34 & 2 & 0 & 30 & 1414 & 75 & 122 \\
\hline 12 & 34 & 4 & 1 & 31 & 1528 & 81 & 136 \\
\hline 13 & 69 & 5 & 4 & 1 & 1677 & 103 & 157 \\
\hline 14 & 96 & 8 & 5 & 2 & 1790 & 112 & 170 \\
\hline 15 & 117 & 8 & 5 & 3 & 1986 & 134 & 181 \\
\hline 16 & 134 & 8 & 5 & 4 & 2092 & 150 & 191 \\
\hline 17 & 172 & 9 & 5 & 5 & 2273 & 164 & 198 \\
\hline 18 & 227 & 11 & 19 & 6 & 2491 & 192 & 209 \\
\hline 19 & 309 & 15 & 25 & 7 & 2738 & 204 & 221 \\
\hline 20 & 369 & 17 & 32 & & & & \\
\hline
\end{tabular}

Based on these data in Table 1, we then plot the data as follows:

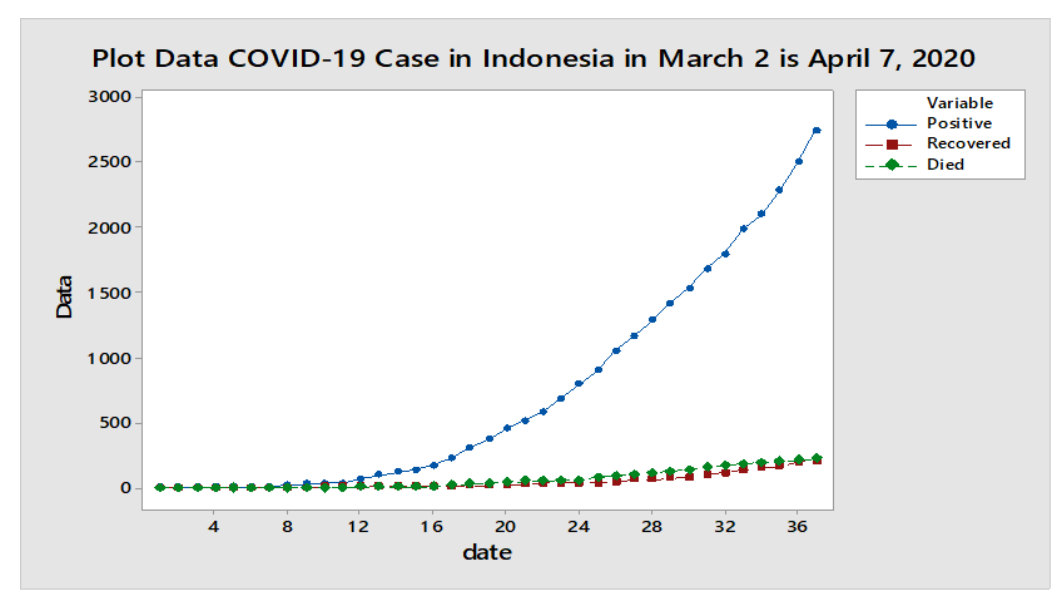

Figure 1. Plot Data COVID-19 in Indonesia

(Data processed by Minitab 18, 2020)

Using the time-series model approach, the pattern of COVID-19 data distribution behavior in Indonesia (Figure 1) shows an exponential distribution pattern, where the addition of positive cases of COVID-19 increases significantly from everyday. This condition is also followed by a pattern of distribution of the number of people who recovered and died.

As we know that in the time-series model the type of exponential distribution consists of a single exponential, double exponential, and Winters' method. In this article, the author further analyzed using the three methods and the best model is the double exponential model. 


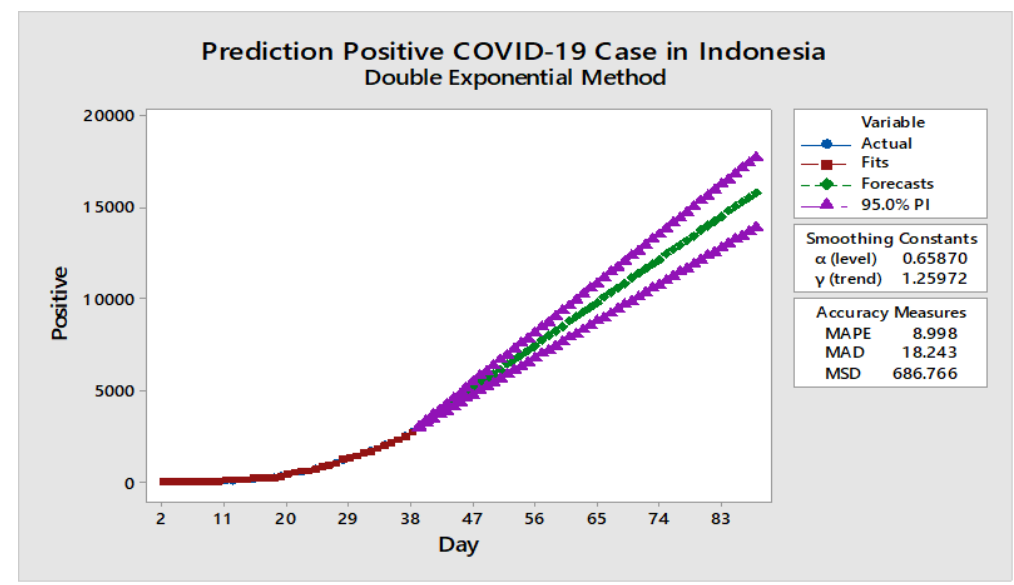

Figure 2. Prediction Positive COVID-19 case in Indonesia (Data processed by Minitab 18, 2020)

By using a 10 percent error rate [Figure 2], the best $\alpha$ parameter values are 0.659 and the best $\gamma$ is 1.260 . with a Mean Absolute Percentage Error (MAPE) of 8.998 percent. MAPE is the error value for each period divided by the actual observation value for that period. In positive COVID-19 case, the MAPE value is smaller than the error rate at $10 \%$ (the exact model is generated).

Figure 1 shows that there are significant differences between positive cases, recovery, and death. Where the decrease in data recovery and death is very far when compared with an increase in the amount of positive data. The increase in the number of people who were positive for COVID-19, also directly affected the model of prediction patients who recovery and death (Figure 3 and Figure 4).

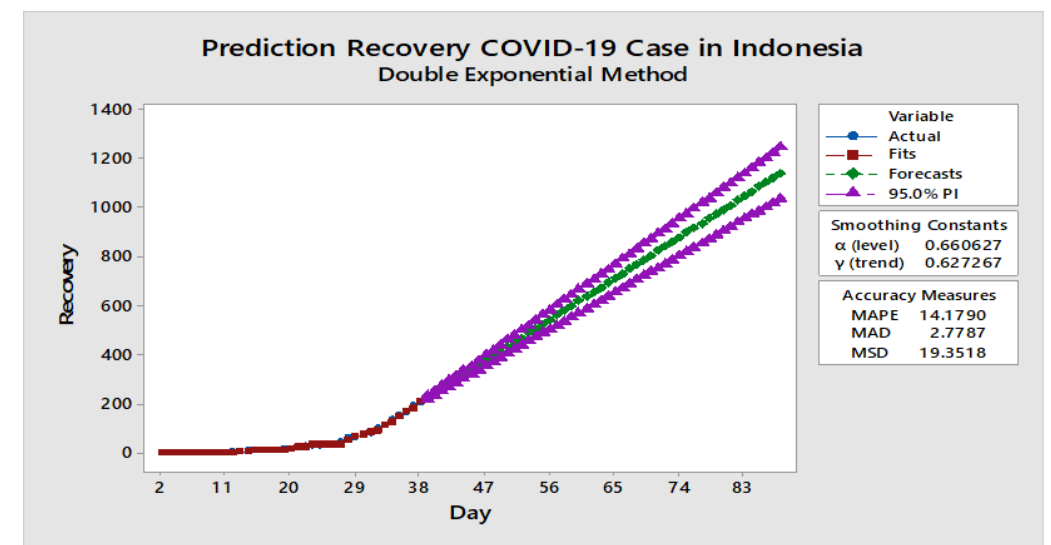

Figure 3. Prediction Recovery COVID-19 case in Indonesia (Data processed by Minitab 18, 2020)

Based on Figure 3. using a 10 percent error rate, the estimated value of the parameter recovery patients at $\alpha$ is $0.660, \gamma$ is 0.627 and the MAPE of 14.179 percent. In the recovery of COVID-19 cases, the MAPE value is greater than the error value set at 10 percent error rate. the still low cure rate of COVID-19 patients is due to the still low awareness of the community to comply with government recommendations. 


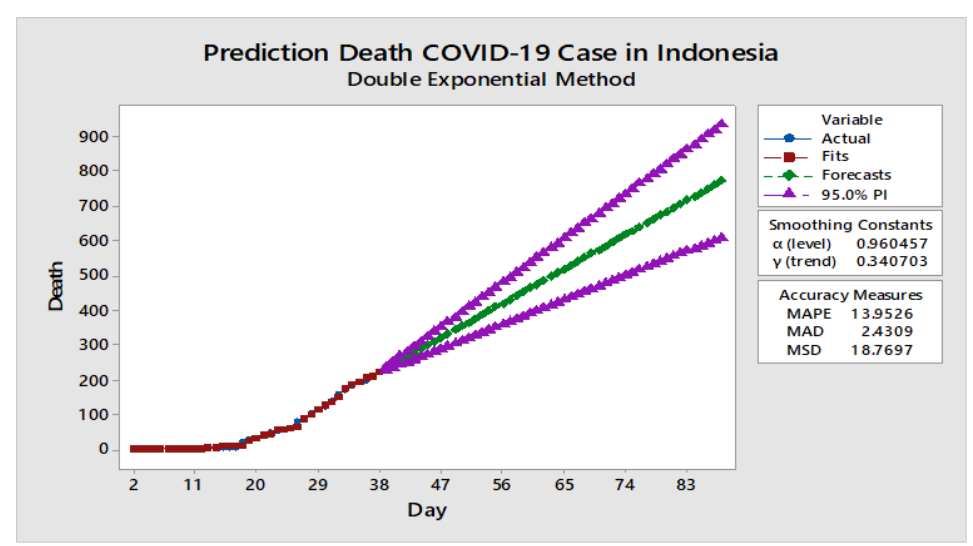

Figure 4. Prediction Death COVID-19 case in Indonesia (Data processed by Minitab 18, 2020)

Figure 4. Using a 10 percent error rate, the estimated value of the parameter death patients at $\alpha$ is $0.9605, \gamma$ is 0.3407 , and the MAPE of 13.95 percent. In the death of COVID19 cases, the MAPE value is greater than the error value set at $10 \%$. the high death rate of COVID-19 patients due to the still limited number of health workers and supporting health facilities to prevent.

After the parameter values, $\alpha$ and $\gamma$ are obtained, the next step is the identification process Partial Autocorrelation Function (PACF) and Autocorrelation Function (ACF) from positive, recovery, and death data. PACF and ACF tests are used to test the accuracy of the results of the double exponential smoothing model and a means of determining the stationarity of the variable and the lag lengths of the ARIMA model.

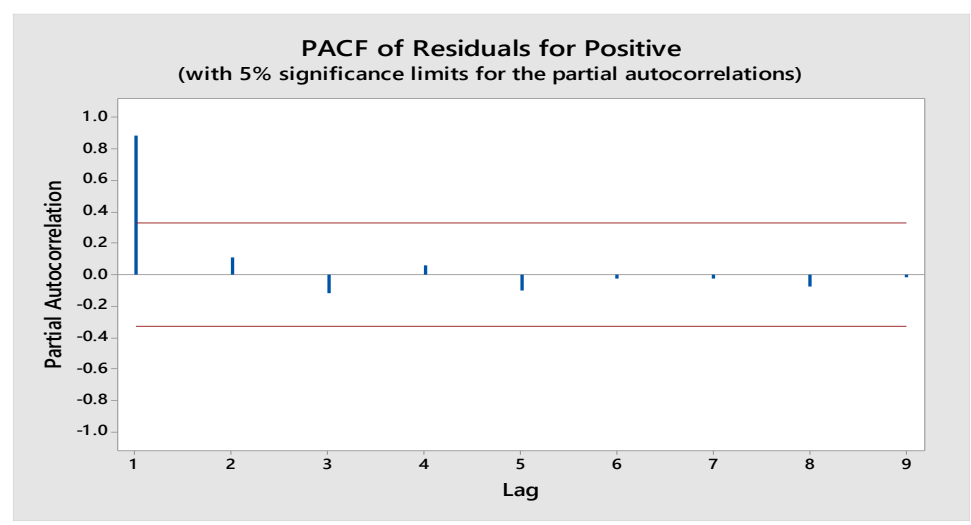

Figure 5. PACF of Residuals for COVID-19 Positive Data (Data processed by Minitab 18, 2020)

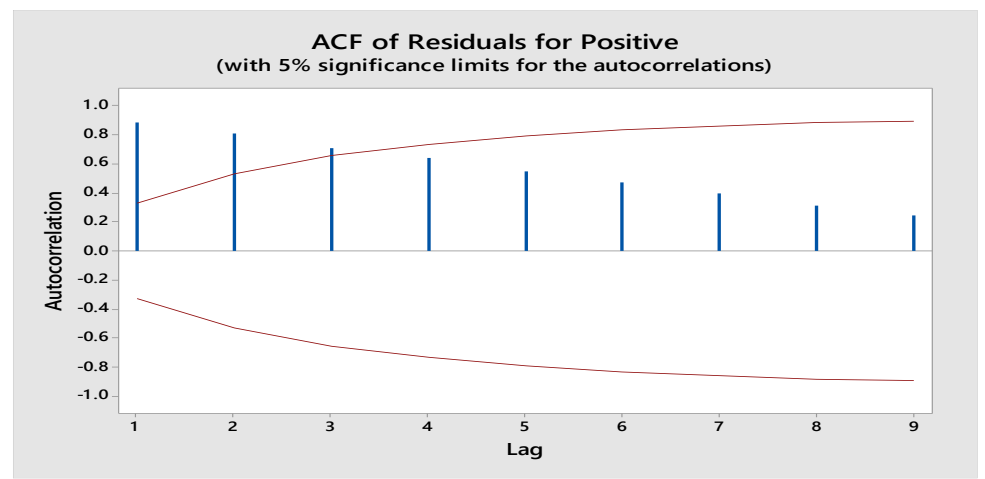

Figure 6. ACF of Residuals for COVID-19 Positive Data

(Data processed by Minitab 18, 2020) 
Based on Figures 5 and 6, PACF and ACF plots of Residuals for COVID-19 positive data are obtained the lag time through PACF cuts off at lag one, and ACF tails off slowly. In the time series model with the error probability $(\alpha) 5 \%$, the graph follows the ARIMA process $(0,1,1)$ with the P-Value MA $1(0.1 \%)$ is smaller than $\alpha$. The estimated results of the ARIMA model as in Table 2.

Table 2. Final Estimates of Parameters Model for COVID-19 Positive data

\begin{tabular}{ccccc}
\hline Type & Coef & SE Coef & T-Value & P-Value \\
\hline MA 1 & -0.592 & 0.161 & -3.67 & 0.001 \\
\hline Constant & 77.4 & 14.0 & 5.51 & 0.000 \\
\hline
\end{tabular}

Differencing: 1 regular difference. Number of observations: Original series 37, after differencing 36.

Referring to equation (4), mathematically the ARIMA model $(0,1,1)$ in Table 2 can be stated as follows: $y_{t}=77.4-0.592 e_{t-1}$

With the same steps as testing positive data, next step the identification process PACF and ACF from recovery data.

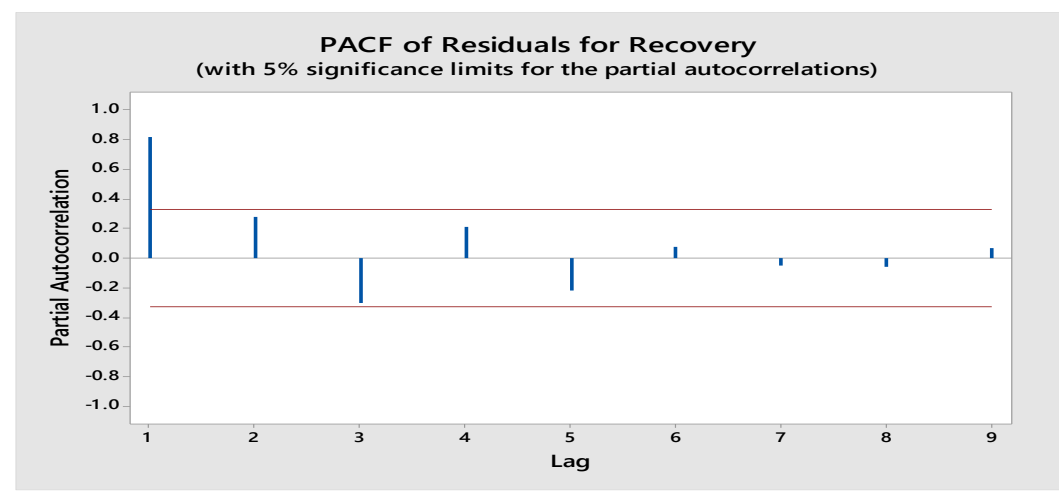

Figure 7. PACF of Residuals for COVID-19 Recovery Data

(Data processed by Minitab 18, 2020)

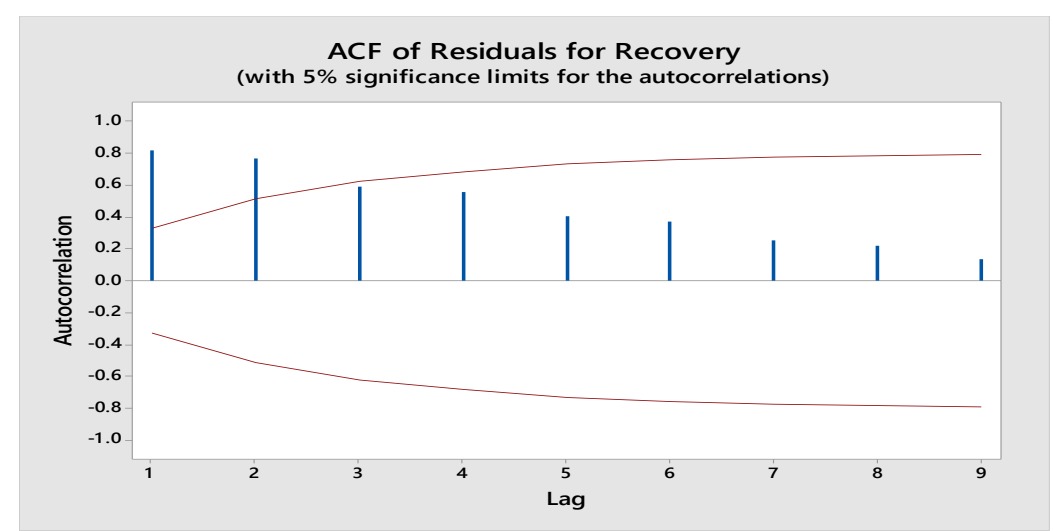

Figure 8. ACF of Residuals for COVID-19 Recovery Data

(Data processed by Minitab 18, 2020)

Same as Covid-19 positive data in Indonesia, Figures 7 and 8 to show PACF and ACF plots of Residuals for COVID-19 Recovery data are obtained the lag time through PACF cuts off at lag one and ACF tails off slowly. In the time series model with the error probability $(\alpha) 5 \%$, the graph follows the ARIMA process $(0,1,1)$ with the P-Value MA 1 $(2.3 \%)$ is smaller than $\alpha$. The estimated results of the ARIMA model as in Table 3. 
Table 3. Final Estimates of Parameters Model for COVID-19 Recovery Data

\begin{tabular}{lrrrr}
\hline Type & Coef & SE Coef & T-Value & P-Value \\
\hline MA 1 & -0.384 & 0.161 & -2.38 & 0.023 \\
\hline Constant & 5.61 & 1.52 & 3.68 & 0.001 \\
\hline
\end{tabular}

Differencing: 1 regular difference, Number of observations: Original series 37, after differencing 36.

Referring to equation (4), mathematically the ARIMA model $(0,1,1)$ in Table 3 can be stated as follows: $y_{t}=5.61-0.384 e_{t-1}$

After positive and recovery data are analyzed, next the PACF and ACF models of the data death will be shown in Figure 9 and Figure 10.

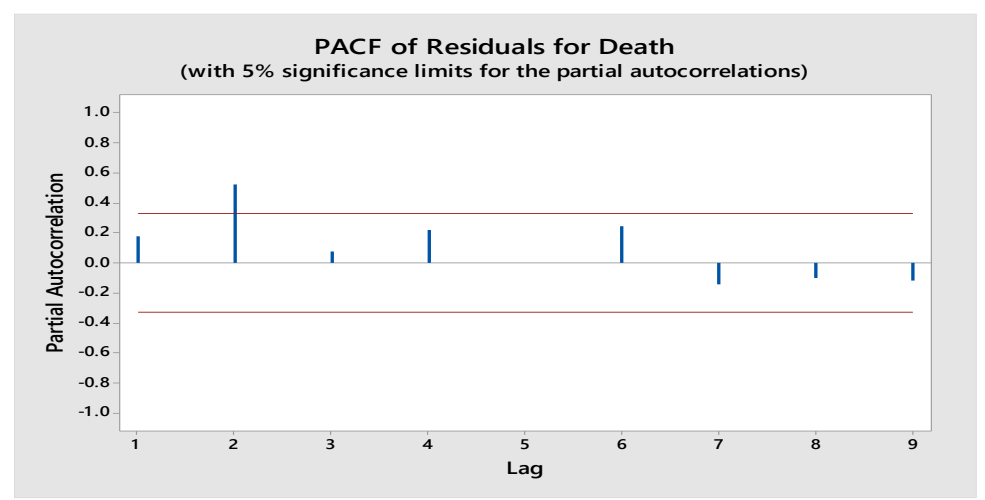

Figure 9. PACF of Residuals for COVID-19 Death Data

(Data processed by Minitab 18, 2020)

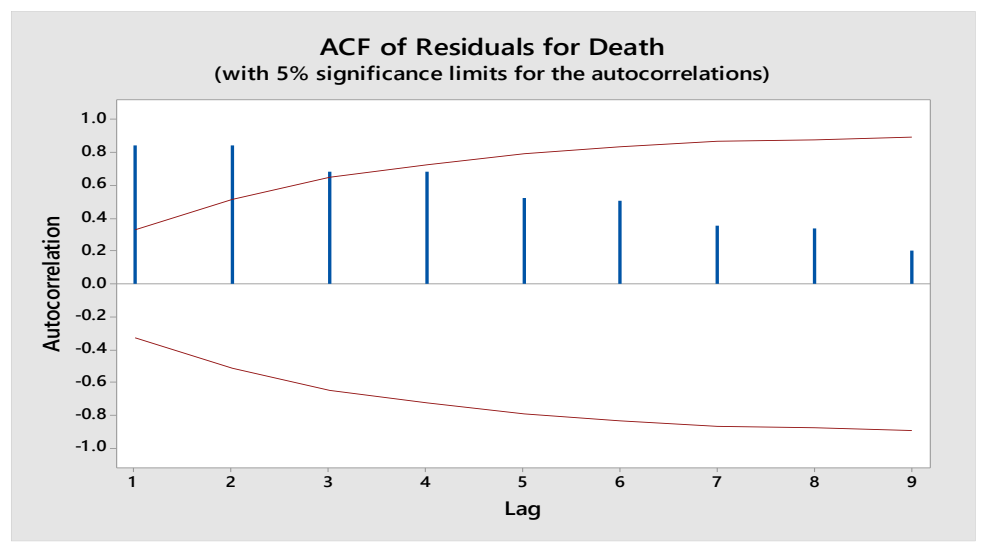

Figure 10. ACF of Residuals for COVID-19 Death Data

(Data processed by Minitab 18, 2020).

Same as Covid-19 positive and recovery data in Indonesia, Figures 9 and 10 to show PACF and ACF plots of Residuals for COVID-19 death data are obtained the lag time through PACF cuts off at lag two and ACF tails off slowly. In time series model with the error probability $(\alpha) 5 \%$, the graph follows the ARIMA process $(0,1,1)$ with the P-Value MA $1(3.6 \%)$ is smaller than $\alpha$. The estimated results of the ARIMA model as in the Table 4. 
Table 4. Final Estimates of Parameters Model for COVID-19 Death Data

\begin{tabular}{ccccc}
\hline Type & Coef & SE Coef & T-Value & P-Value \\
\hline MA 1 & -0.351 & 0.161 & -2.18 & 0.036 \\
\hline Constant & 6.14 & 1.28 & 4.81 & 0.000 \\
\hline
\end{tabular}

Differencing: 1 regular difference. Number of observations: Original series 37, after differencing 36

Referring to equation (4), mathematically the ARIMA model $(0,1,1)$ in Table 4 can be stated as follows: $y_{t}=6.14-0.351 e_{t-1}$

Based on the results of predictions of COVID-19 cases that occurred in Indonesia with a double exponential model and the results of PACF, ACF and estimated parameters model following the ARIMA model $(0,1,1)$ with the P-Value MA 1 is smaller than $\alpha$. The results of predictions of COVID-19 cases that occurred in Indonesia (positive, recovery, and death) showed a gap in the resulting distribution patterns. Where the increase in the number of positive cases has not been offset by an increase in the number of patients who recovery and a decrease in the number of patients who died. This indicates that public behavior still does not comply with the rules set by the government (social distancing, large-scale social restrictions (PSBB), mask use), the limited medical staff and the lack of standard equipment handling COVID-19 is one of the causes of the low handling of healing from positive patients.

\section{Conclusions}

Based on the analysis of data patterns of behavior of people who tested positive, recovery, and death with a time-series approach, it was found that the COVID-19 distribution model in Indonesia followed with the double exponential model. The results of PACF, ACF, and estimated parameters model following the ARIMA model $(0,1,1)$. Where are the results of predictions of COVID-19 cases that occurred in Indonesia (positive, recovery, and death) showed a gap in the resulting distribution patterns.

\section{References}

[1] Y. Yuliana, "Corona virus diseases (Covid-19): Sebuah tinjauan literatur. Wellness And Healthy Magazine, Vol. 2, No. 1, pp. 187 - 192, February 2020. Retrieved from https://wellness.journalpress.id/wellness/article/view/21026

[2] Worldometer, "Covid-19 Coronavirus Pandemic", worldometer, 2020. [Online], Available: $\quad$ https://www.worldometers.info/coronavirus/country/indonesia/, (Accessed: April 6, 2020.

[3] A. M. Idhom, "Update Corona 6 April 2020 Indonesia \& Data Covid-19 Dunia Terbaru", tirto.id. [Online]. Available: https://tirto.id/update-corona-6-april-2020Indonesia-Data-COVID-19-Dunia-Terbaru-eLk5. (Accessed: April 7, 2020).

[4] Badan Nasional Penanggulangan Bencana, "Jumlah Kasus COVID-19 Global dan Indonesia", Gugus Tugas Percepatan Penanganan COVID-19. [Online]. Available: http://covid19.bnpb.go.id/. (Accessed: April 7, 2020).

[5] S. Supriyono, S. Siswanto, and W. Wuryanto, "Model Matematika Penyebaran Flu Burung dari Unggas," Unnes Journal of Mathematics, vol. 2, no. 1, pp. 32-38, May 2013. 
[6] S. Toaha and K. Khaeruddin, "Model Sir Untuk Penyebaran Penyakit Flu Burung", Jurnal Matematika, Statistika, dan Komputasi, vol. 10, no. 2, pp. 82-91, January 2014.

[7] J. T. Wu, K. Leung, and G. M. Leung, "Nowcasting and forecasting the potential domestic and international spread of the 2019-nCoV outbreak originating in Wuhan, China: a modeling study," THE LANCET, vol. 395, issue 10225, pp. 689-697, February 29, 2020. DOI:https://doi.org/10.1016/S0140-6736(20)30260-9

[8] Q. Lin, et al., "A conceptual model for the coronavirus disease 2019 (COVID19)outbreak in Wuhan, China with individual reaction and governmental action," International Journal of Infectious Diseases, vol. 93, pp. 211-216, April 2020. DOI:https://doi.org/10.1016/j.ijid.2020.02.058

[9] Y. Li, et al., "Mathematical Modeling and Epidemic Prediction of COVID-19 and Its Significance to Epidemic Prevention and Control Measures," Annals of Infectious Disease and Epidemiology, vol. 5, issue 1, pp. 1-9, Mar 2020.

[10] S. Makridakis, Metode dan Aplikasi Peramalan Jilid 1 (Edisi Revisi). Jakarta: Binarupa Aksara, 2003. 